\title{
GAPDH spike RNA as an alternative for housekeeping genes in relative gene expression assay using real-time PCR
}

\author{
Zeenah Weheed Atwan
}

\begin{abstract}
Background and aim of study: $\mathrm{QPCR}$ is a robust technique which quantifies the expressions of target genes in relation to reference genes. Stresses such as virus infection or heat shock change expressions of many cellular genes including the reference genes, so the aim was to introduce a constant calibrator to normalize the data to.

Methodology: Constructed glyceraldehyde 3-phosphate dehydrogenase (GAPDH) plasmid was transcribed to GAPDH RNA and used as spike RNA. Spiked RNA samples were subjected to qPCR at different conditions such as virus infection, IFN treatment, or mild heat shock.

The results: Adenovirus hexon in interferon-deficient cells showed different expression levels when data were normalized to GAPDH or 18S. Consistently, hexon expression levels were different in untreated cells under the control or heat-shocked conditions when data were normalized to GAPDH or 18S. Promyelocytic leukemia protein II (PML-II) expression level was lower in HeLa-PML-II-deficient cells (PML-II-Kd) compared to the control when the data were normalized to GAPDH as a reference gene and also in GAPDH RNA spiked, which showed reasonable consistency. More consistent data were obtained when the GAPDH normalizer was added before the step of treating the extracted RNA with DNase compared to add it after the treatment or directly to the qPCR reaction.

Conclusion: The internal controls that were chosen for this study completely changed the experimental results since they were affected with the experimental conditions. However, GAPDH spike RNA level was stable in its amplification at different kinds of stresses. So it can be an alternative for housekeeping gene due to its stability at these different conditions.
\end{abstract}

Keywords: Spike RNA, qPCR, Relative expression, Housekeeping genes, Universal normalizer

\section{Introduction}

More than two decades ago, a video camera was used to monitor the amplification of DNA fragment over a course of thermocycling (Higuchi et al., 1993). The quantitative real-time PCR was firstly used to quantify the levels of cystic fibrosis transmembrane transduction regulator (CFTR) mRNA. Relying on $5^{\prime}$ exonuclease activity of Taq polymerase and tetrachlor-6-carboxy-fluorescen as a reporter dye, an internal probe was designed to detect the CFTR in real time with a parallel control that was detected using specific primer with a different internal DNA probe (Gibson et al., 1996).

Correspondence: za_zeenah@yahoo.com

Biology Department, College of Science, University of Basrah, Basrah, Iraq
Similar to many quantitative assays, qPCR has many troubleshootings either in PCR steps or in the fluorescence problems (Bustin, 2000). To quantify mRNA expression, researchers developed a method using SYBR green or recRNA or recDNA (Pfaffl \& Hageleit, 2001).

In order to normalize the expression of any target gene, it is critical to choose the most stable gene which expression unaffected by different conditions or at least the conditions in a certain experiment. For example, GAPDH, $\beta$-actin, and 18S RNA are the most common housekeeping or control genes, but in all cases, it is necessary to optimize the conditions to choose the right control before starting. Prior to do the qPCR experiment, it is very important to choose a reference gene that does not change under the experiment conditions 
to ensure that the alteration in gene expression is due to the target gene not to the control gene (Livak \& Schmittgen, 2001).

qPCR is a very sensitive assay, and it needs sequential steps starting from RNA or DNA extraction and reverse transcription and ending with the qPCR (Skern et al., 2005). In addition, there is no reference gene that stays stable over different types of stresses or cellular treatments even the very common reference genes such as GAPDH or $\beta$-actin. So these housekeeping genes were reintroduced as unreliable control genes as their expression is changing with treatments and alternatives were introduced to the field (Radonić et al., 2004). Virus infection as one kind of stress interferes with many cellular pathways, so it changes the regular expression of many genes including the housekeeping genes, such as the human cytomegalovirus (HCMV) infection. HCMV infection alters the expression of wide range of genes responsible for repression and stimulation of cellular transcription and post-translational modifications (Kalejta \& Shenk, 2002). So many studies started to detect the most stable reference gene during infection with different types of viruses in different cell lines (Radonić et al., 2005).

The reference or control could be an active control which gives a detectable signal during the GPCR run, and it could be internal or external; the internal is an RNA that is extracted in the same sample and the signal of the target gene is normalized to, while the external means adding a synthetic spike RNA or DNA to the extracted RNA and the data are normalized to that foreign nucleic acid (Livak, 1997).

Using external standard RNA is very important to compensate the function of the internal control as a constant calibrator (Jiang et al., 2011). Such artificial molecules are either made as aliens where they are made as pool sequences which do not belong to any known genome and cloned in a vector or they could be reference known-sequence gene that is cloned and added to the test samples artificially during the RNA extraction step. Despite that this RNA will be ideal for normalization as it will not be affected by treatment as the internal control does, it did not come from the same cells or tissues so it will need to be validated beforehand (Cronin et al., 2004; Huggett et al., 2005). Based on the need to build unbiased conclusions when analyzing gene expression by real-time PCR, the plan was to analyze the gene expression of some target genes under different types of stresses such as mild heat shock and adenovirus infection. So the aim was to analyze the expression of hexon (late adenovirus gene) and promyelocytic leukemia protein isoform II (PML-II) (interferon-regulating gene) under normal or slightly higher temperature normalized to selected housekeeping genes or to GAPDH spike RNA.

\section{Materials and methods}

\section{Construction of GAPDH DNA plasmid}

Genomic GAPDH insert was constructed from a subculture of HeLa cells which was used as a DNA source. DNA was extracted by column-based purification technique which was provided by Sigma-Aldrich GenEluteTM Mammalian Genomic DNA Miniprep Kit (G1N70). DNA samples were extracted by following the manufacturer's instructions, and the eluted DNA was stored at $-20^{\circ} \mathrm{C}$. A fragment of $97 \mathrm{bp}$ was amplified by GAPDH-specific primers using an Eppendorf Master Cycler Gradient Thermo-cycler and Taq DNA polymerase. The conventional PCR reaction mixture was prepared as follows:

\begin{tabular}{lll}
\hline & Reagent & Concentration/amount \\
\hline 1 & DNA template & $50 \mathrm{ng} / \mu \mathrm{l}$ \\
2 & Forward and reverse primers & $1 \mu \mathrm{l}$ of $20 \mathrm{mM}$ \\
3 & dNTPs & $1 \mu \mathrm{l} \mathrm{of} 20 \mathrm{mM}$ \\
4 & $\mathrm{MgCl}_{2}$ & $50 \mathrm{mM}$ \\
5 & $\mathrm{H}_{2} \mathrm{O}$ & Completed to $50 \mu \mathrm{l}$ \\
\hline
\end{tabular}

The thermal cycle was set as follows: $94{ }^{\circ} \mathrm{C}$ for $3.5 \mathrm{~min}$, $30 \mathrm{~s}$ at $60^{\circ} \mathrm{C}$, and $7 \mathrm{~min}$ at $70^{\circ} \mathrm{C}$. Using QIAquick PCR purification kit, the amplified GAPDH was further purified according to the manufacturer's directions. Ligation was achieved by mixing $2 \times$ pGEMT rapid ligation buffer (PGEM R-T Easy Vector Promega) at a ratio of 3:1 insert to vector in a total volume of $10 \mu \mathrm{l}$, according to the manufacturer's instructions. Fifty percent of the mixture was used to transform $100 \mu \mathrm{l}$ of $E$. coli competent DH5 $\alpha$ cells and plated on. White-blue selection was achieved by preparing XGAL/IPTG LB ampicillin plates by mixing $40 \mu \mathrm{l}$ of $20 \mathrm{mg} / \mathrm{ml}$ XGAL with $40 \mu \mathrm{l}$ of $100 \mathrm{mM}$ IPTG and spread on the surface of the sterile LB-Amp agar plates. Positive colonies (white) were grown in $5 \mathrm{ml}$ of LB broth containing $100 \mu \mathrm{g} / \mathrm{ml}$ ampicillin for $16 \mathrm{~h}$ at $37^{\circ} \mathrm{C}$. The growth then used to purify GAPDH plasmids and purified using QIAprep Spin Miniprep Kit and finally sent to GATC Biotech to determine correct DNA sequence (Atwan, 2016).

\section{GAPDH plasmid linearization}

The reaction mixture was prepared by mixing $4 \mu \mathrm{l}$ of NEB $10 \times$ buffer, $2 \mu \mathrm{l}$ of $500 \mathrm{ng} / \mu \mathrm{l}$ of GAPDH plasmid, and $1 \mu \mathrm{l}$ of ECORI restriction enzyme, and the reaction was completed to $10 \mu \mathrm{l}$ by $\mathrm{H}_{2} \mathrm{O}$. The mixture then left at $37^{\circ} \mathrm{C}$ in water bath for $1 \mathrm{~h}$. The digestion was stopped by adding $0.5 \mu \mathrm{l}$ of $0.5 \mathrm{M}$ EDTA, $1 \mu \mathrm{l}$ of $3 \mathrm{M} \mathrm{Na}$ acetate, and $20 \mu \mathrm{l}$ of ethanol. The mixture then cooled at $-20^{\circ} \mathrm{C}$ for $30^{\prime}$ ', and the linearized DNA then precipitated by $14 \mathrm{~K}$ micro-centrifuge for 15 '. Supernatant was removed, 
and the tube was re-spun again for few seconds to remove the residual liquid phase; then, DNA was resuspended in $\mathrm{H}_{2} \mathrm{O}$ at a concentration of $1000 \mathrm{ng} / \mu \mathrm{l}$.

\section{In vitro transcription}

All the kit reagents were briefly centrifuged before using, and all of them except the $10 \times$ reaction buffer were left on ice; then, the reaction mixture was prepared as in the table below:

\begin{tabular}{ll}
\hline The reagent & Amount \\
\hline ATP solution & $2 \mu \mathrm{l}$ \\
CTP solution & $2 \mu \mathrm{l}$ \\
GTP solution & $2 \mu \mathrm{l}$ \\
UTP solution & $2 \mu \mathrm{l}$ \\
10X reaction buffer & $2 \mu \mathrm{l}$ \\
Linearized GAPDH plasmid & $1 \mu \mathrm{g}$ \\
RNA polymerase enzyme mix & $2 \mu \mathrm{l}$ \\
$\mathrm{H}_{2} \mathrm{O}$ & To $20 \mu \mathrm{l}$ \\
\hline
\end{tabular}

The reaction was mixed thoroughly and briefly microcentrifuged and was left at 37 for $8 \mathrm{~h}$.

The reaction was stopped by adding $115 \mu$ l of $\mathrm{H}_{2} \mathrm{O}$ and $15 \mu \mathrm{l}$ of ammonium acetate stop solution.

The RNA was purified using column kits provided by Promega SV total RNA isolation system z3100, and according to the manufacturer's instructions, the purified RNA was then eluted with nuclease-free water at a concentration of $600 \mathrm{ng} / \mu \mathrm{l}$ measured by NanoDrop.

\section{Stable transduced HeLa cells}

Permanent PML-II depleted cells, control empty vector EV, or GFP cells were produced by genetic modification using the lentiviral system to deliver the anti-PML-II, EV, or GFP constructs into HeLa cell genome to investigate the function of PML-II gene in adenovirus life cycle (Atwan, 2016).

\section{Heat shock protein 70 (HSP70)}

Hsp70 mRNA in HeLa cells was transiently interfered with HSP70 siRNA (Atwan, 2016) to reduce the gene expression of HASA1 and HSPB1.

\section{qPCR assay}

PML-II, EV, or GFP cells were plated on at a density of $1 \times$ $10^{5} \mathrm{cell} / \mathrm{ml} ; 24 \mathrm{~h}$ later, both types of cells were infected with adenovirus type 5 wild type with multiplicity of infection of 5. Twenty hours later, cells were washed with PBS, then were lysed and used as a source of adenovirus-infected RNA which was extracted by Promega SV total RNA isolation system z3100, and according to the manufacturer's instructions, the purified RNA was then eluted with a nuclease-free water. The RNAs were DNase treated and reverse transcribed to cDNA by GoScript ${ }^{\mathrm{TM}}$ reverse transcription system A5000 and according to the manufacturer's protocol. Then, qPCR reaction was prepared by mixing $0.1 \mu \mathrm{l}$ of $20 \mu \mathrm{M}$ hexon and IFN forward and reverse primers, $10 \mu \mathrm{l}$ of SYBR green reaction mix, and $0.3 \mu \mathrm{l}$ (Agilent). For hexon and IFN gene expression, the adenovirus cDNA were used at a concentration of $5 \mathrm{ng} / \mu \mathrm{l}$ as the DNA template; the qPCR experiments were achieved by Stratagene MX3005P light cycler (Agilent Technologies) under $95^{\circ} \mathrm{C}$ for $3 \mathrm{~min}$, then cycles of $1 \mathrm{~min}$ at $95^{\circ} \mathrm{C}, 30 \mathrm{~s}$ at $55^{\circ} \mathrm{C}$, and $30 \mathrm{~s}$ at $95^{\circ} \mathrm{C}$ thermal cycles. Cycle threshold and baseline values were determined using the machine software, and viral or cellular products were subjected to dissociation curve analysis to ensure primer specificity; all the primers which were used in this work are listed in Table 1.

Table 1 qPCR primer sequences

\begin{tabular}{|c|c|c|c|}
\hline Primer & Forward sequence & Reverse sequence & Reference \\
\hline gGAPDH & CCCCACACACATGCACT & CCTAGTCCCAGGGCTIT & Krog et al. 2007 \\
\hline $\mathrm{H}$ & TACC & GATT & \\
\hline \multirow[t]{2}{*}{ PML-II } & AGGCAGAGGAACGCGT & GGCTCCATGCACGAGTT & Chen 2014 \\
\hline & TGT & $\pi \mathrm{C}$ & \\
\hline \multirow[t]{2}{*}{ ISG56 } & GCCATTTCTTTGCTTC & TGCCCTTITGTAGCCTC & Chen 2014 \\
\hline & CCCTA & $\mathrm{CTTG}$ & \\
\hline \multirow[t]{2}{*}{ GAPDH } & GGTCGGAGTCAACGGA & CCAGCATCGCCCCACTT & Vestergaard et al. 2010 \\
\hline & $\pi T$ & G & \\
\hline \multirow[t]{2}{*}{$18 \mathrm{~S}$} & ACGCTGAGCCAGTCAG & CTTAGAGGGACAAGTG & Menager et al. 2009 \\
\hline & TGTA & GCG & \\
\hline \multirow[t]{2}{*}{ HSP70 } & AGGCCAACAAGATCAC & TCGTCCTCCGCTTGTAC & Tanaka et al. 2007 \\
\hline & CATC & $\pi$ & \\
\hline Hexon & CGCTGGACATGACTTITGAG & GAACGGTGTGCGCAGG TA & Schreiner et al. 2013 \\
\hline
\end{tabular}


The data analyses were calculated as Cts after subtracting housekeeping gene $\mathrm{Ct}$ values from the gene of interest.

\section{Results}

\section{Observation}

One of the early observations during working with qPCR assays is the variation in the internal control amplification with the treatment. Genetically modified cells, and PML-II depleted and control cells GFP were used to analyze adenovirus gene expression. In a try to compare the expression of hexon, one of the late gene expressed proteins in adenovirus infected cell. Hexon expression showed dramatic variability in its mRNA level using different internal controls. In the first experiment, the hexon expression which is the target gene was expressed 3 Cts earlier in PML-II depleted cells compared to GFP control cells (Fig. 1) which is very expected as PML-II protein is regulating the interferon type I response (Chen et al., 2015). Despite this dramatic change in adenovirus hexon, when data were normalized to GAPDH as an internal control, the expression of hexon was roughly the same in both types of cell lines (Fig. 1).

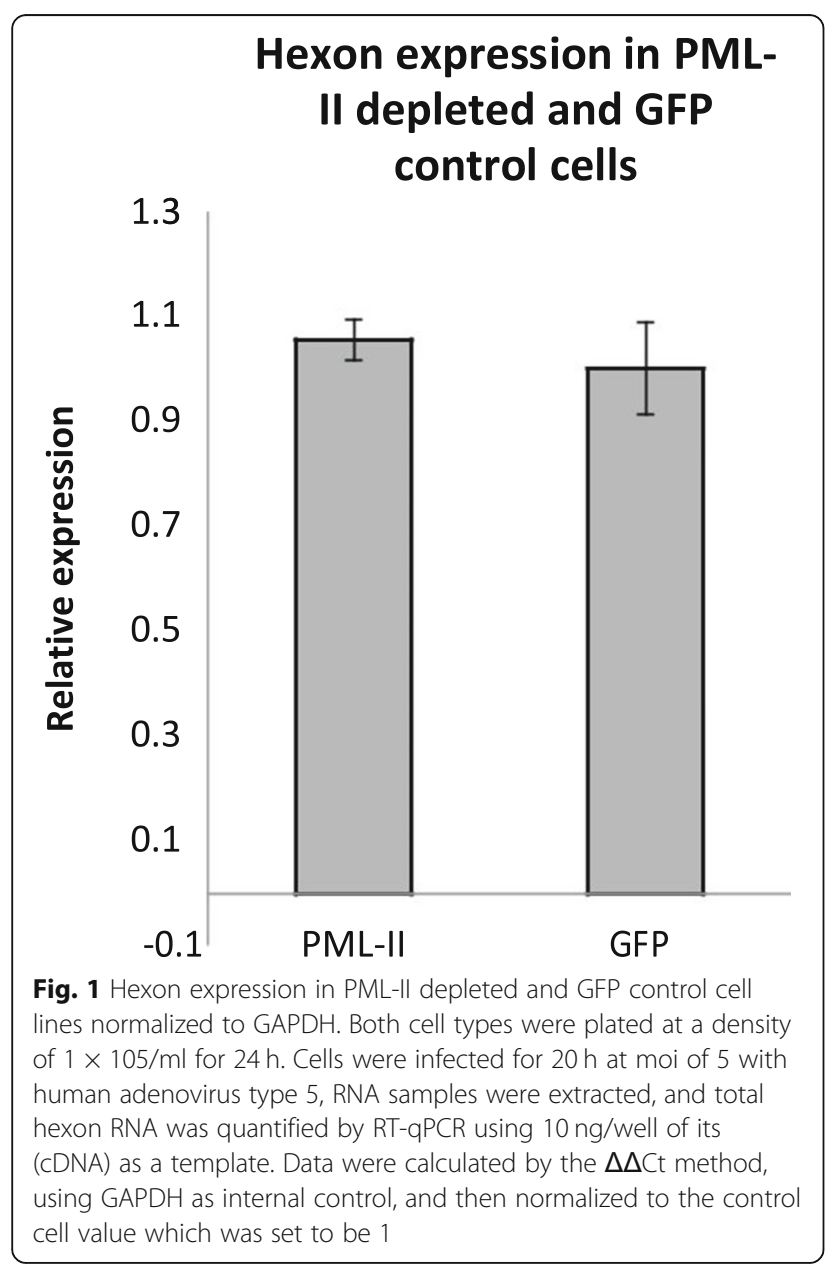

The whole biological experiment was repeated under the same conditions except the housekeeping gene normalizer. The GAPDH was replaced this time with 18S. In a clear consistency, the hexon mRNA expression appeared $3 \mathrm{Cts}$ earlier than its expression in the control cells (Fig. 2). In contrast to the first experiment, there was a dramatic increase in hexon expression in PML-II depleted cells compared to the control after normalizing data to $18 \mathrm{~S}$ (Fig. 2).

\section{Normalization of qPCR data under physical stress in control cells}

Applying different kinds of treatment for the cell culture and quantifying the viral gene expression afterwards needed pre-optimization to consider results that welcome out of the qPCR assay. Both PML-II depleted and control cells were exposed to 40 for about $3 \mathrm{~h}$ then infected with adenovirus type 5 for $20 \mathrm{~h}$ before extracting RNA from the 2 types of cells and under treatment and normal conditions. Again, the data varied drastically depending on the chosen housekeeping gene. When hexon expression was normalized to GAPDH, it showed higher level at stress conditions compared to the control (Fig. 3), while it

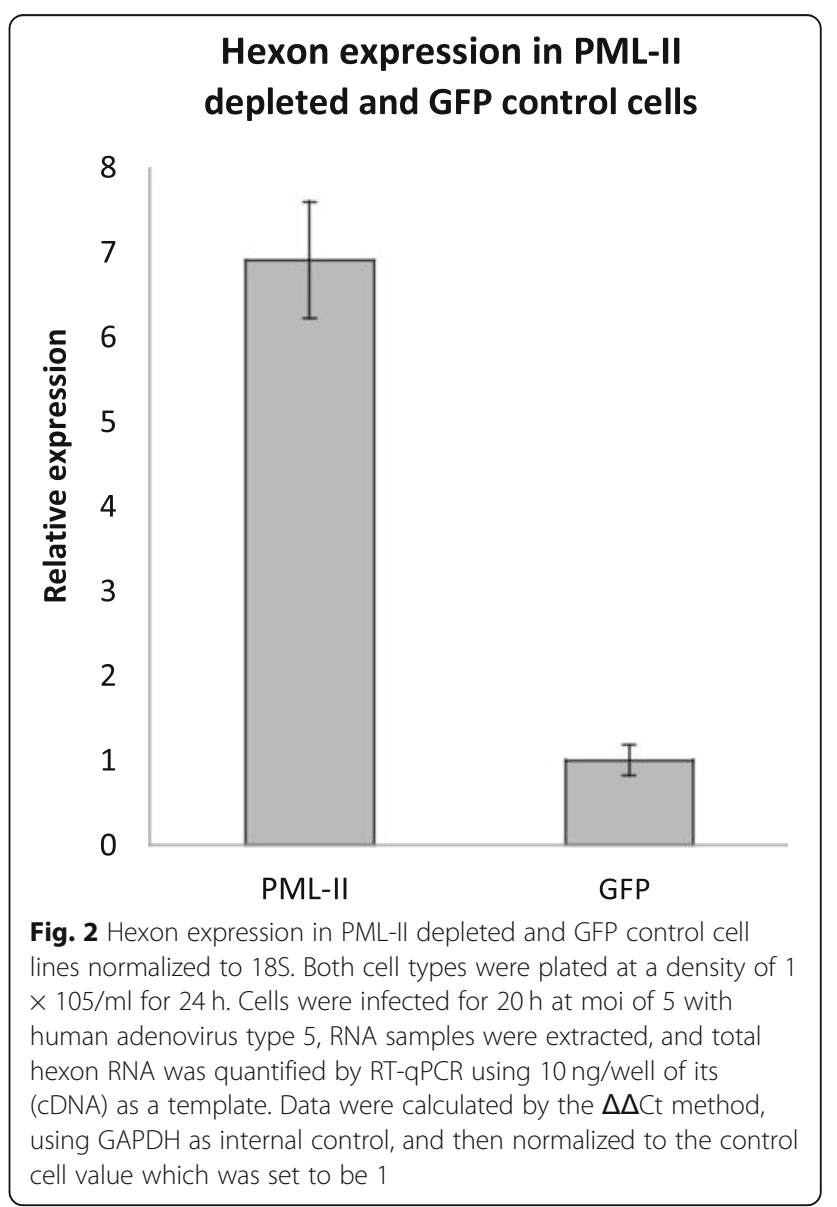


showed much lower expression at stress conditions compared to the control when the data were normalized to $18 \mathrm{~S}$ as the reference gene (Fig. 4).

Normalization to 18 in Fig. 4 is more accurate than in Fig. 3 as the internal control in both treated and nontreated samples as its Cts values changed within narrow range between 0.1 and 0.5 which seemed very stable compared to the GAPDH which varied in about 14 Cts. Additionally, the $18 \mathrm{~S}$ normalized results showed good consistency with Atwan's (2016) conclusion that the mild stress decreases adenovirus late gene expression which was confirmed by protein analysis.

\section{Spiking RNA samples with synthetic spike RNA}

In order to compare the stability of GAPDH mRNA expression, the PML-II mRNA level was measured in both PML-II depleted cells compared to the empty vector control cells. As it is expected, the PML-II depleted cells will have lower level of PML-II mRNA in comparison with control cells. In fact, this was the case in both unspiked and spiked

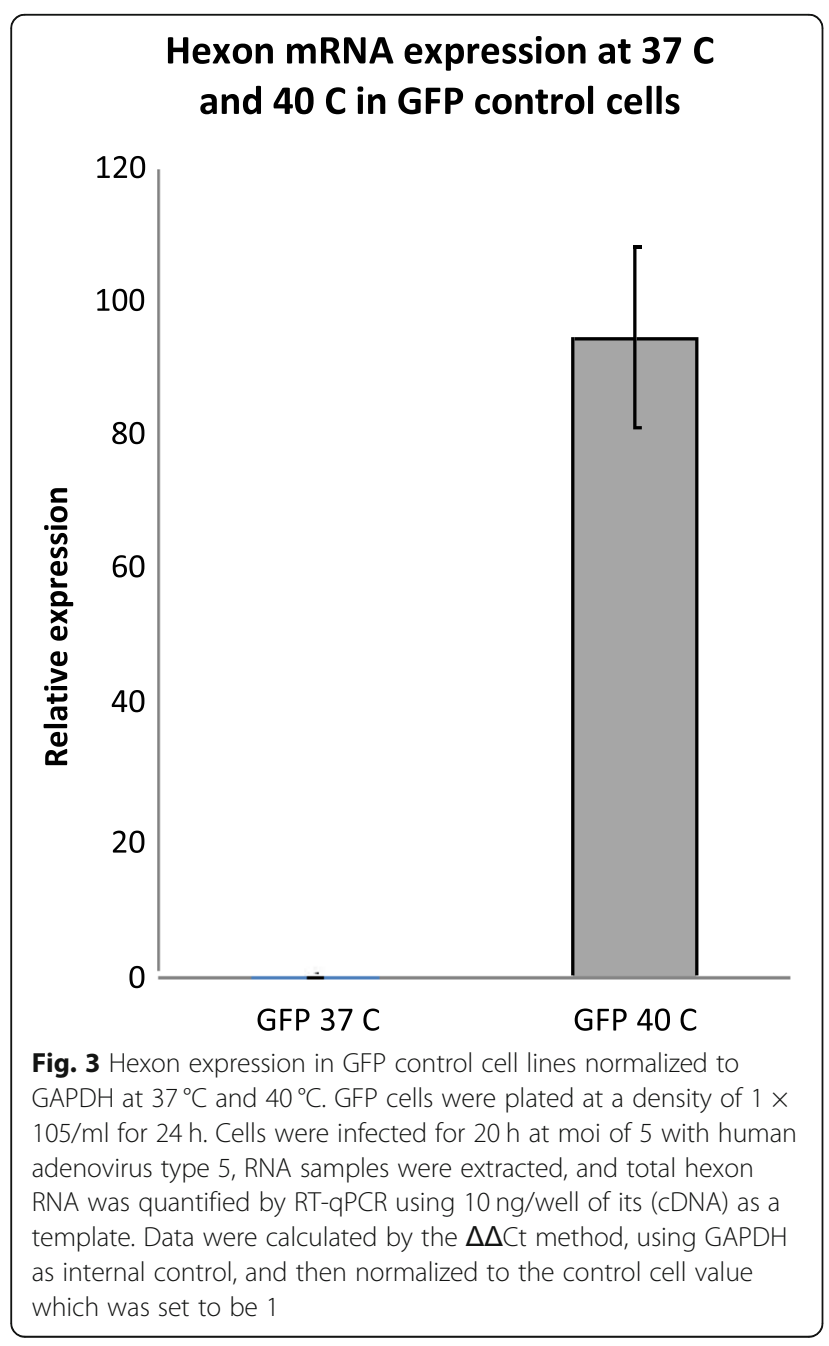

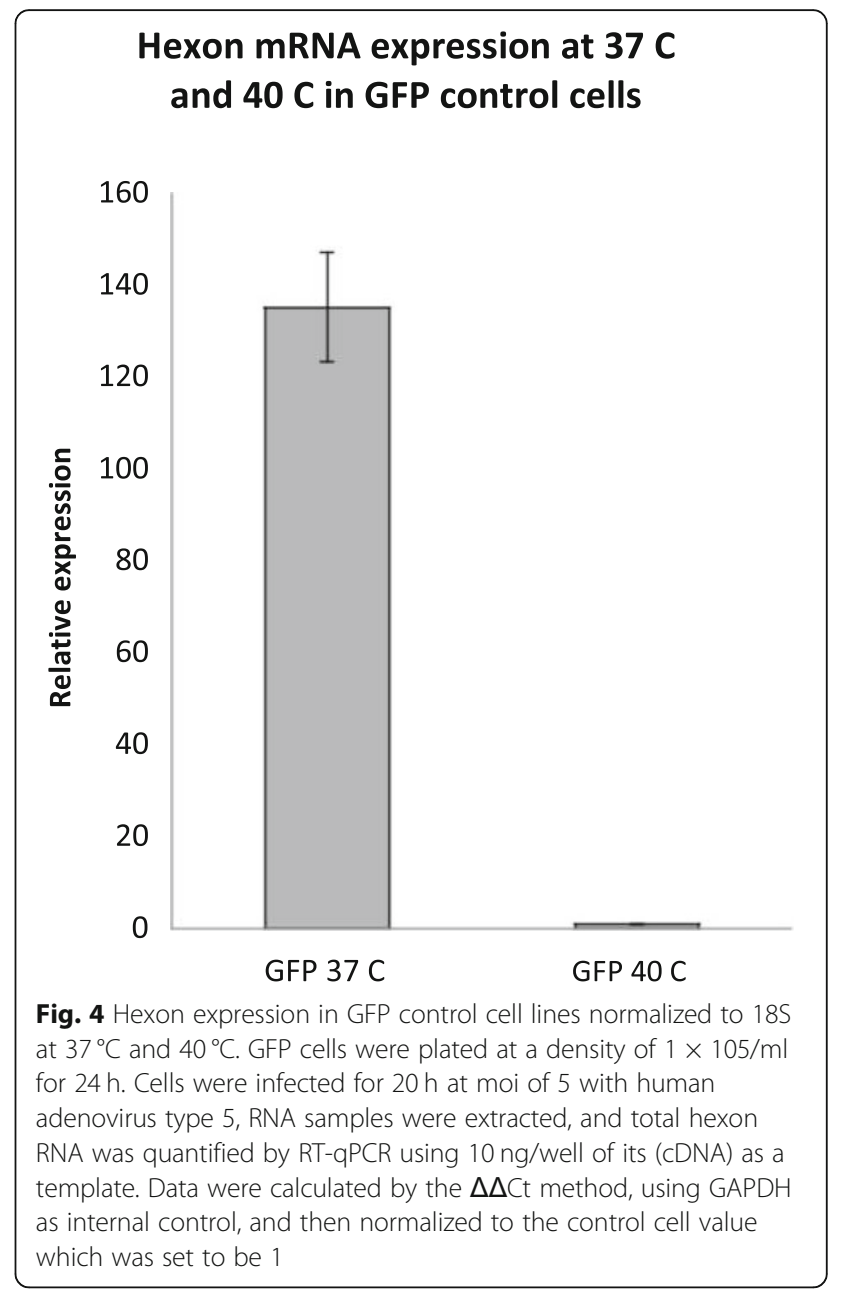

samples despite the latter showed more dramatic effect as a consequence of PML-II m RNA depletion (Fig. 5a, b).

\section{Stage of adding the spike RNA}

One of the important practical questions that need to be answered is at what stage one should contaminate the samples under investigation? To answer such question, it is important to try different stages of RNA extraction to rule out the right stage to work through. In this experiment, the spike RNA was added at the beginning of RNA extraction and before DNase treatment or after DNase treatment or added directly to the qPCR reaction well to investigate the level of interferon stimulated gene 56 (ISG56) in EV control cell line in the presence or absence of heat shock protein 70 (HSP70). Adding the spike RNA before DNase treatment showed difference in about 2 CTs in GAPDH message, and window of variance became narrower when spike RNA was added after DNase treatment and before reverse transcription step (Fig. 6). The GADH message changed between treated and untreated samples in about $0.8 \mathrm{Ct}$ value. The last group of samples was contaminated with spike RNA 


\section{PML-II mRNA normalised to GAPDH mRNA}

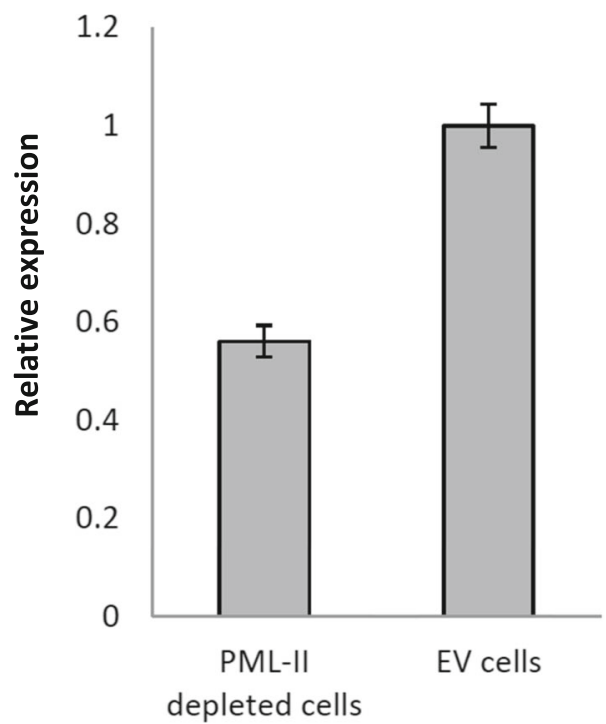

PML-II mRNA in spiked samples normalised to GAPDH mRNA

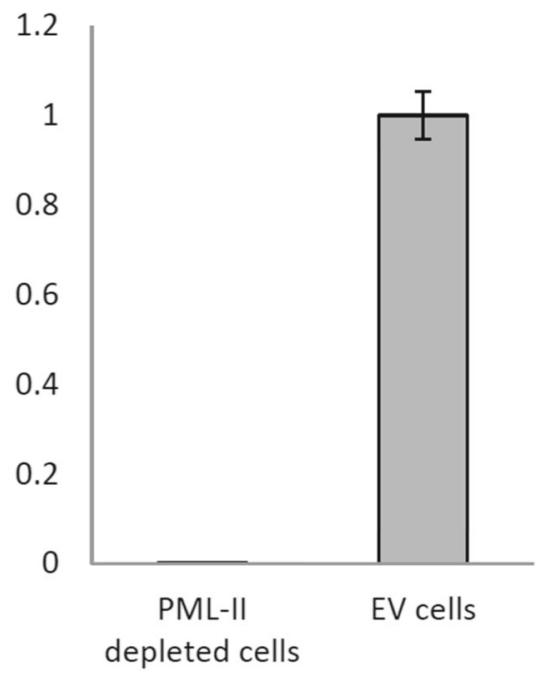

Fig. 5 PML-II expression in PML-II depleted and EV control cells. Cells were plated at a density of $1 \times 105 / \mathrm{ml}$ for $24 \mathrm{~h}$. RNA samples were extracted either directly or spiked with $1 \mathrm{ng}$ of GAPDH RNA or left as a regular extracted RBA. Total PML-II RNA was quantified by RT-qPCR using $10 \mathrm{ng} /$ well of its (CDNA) as a template. Data were calculated by the $\Delta \Delta \mathrm{Ct}$ method, using GAPDH as internal control, and then normalized to the control cell value which was set to be 1. a Normalized to GAPDH mRNA. b Normalized to spike GAPDH mRNA

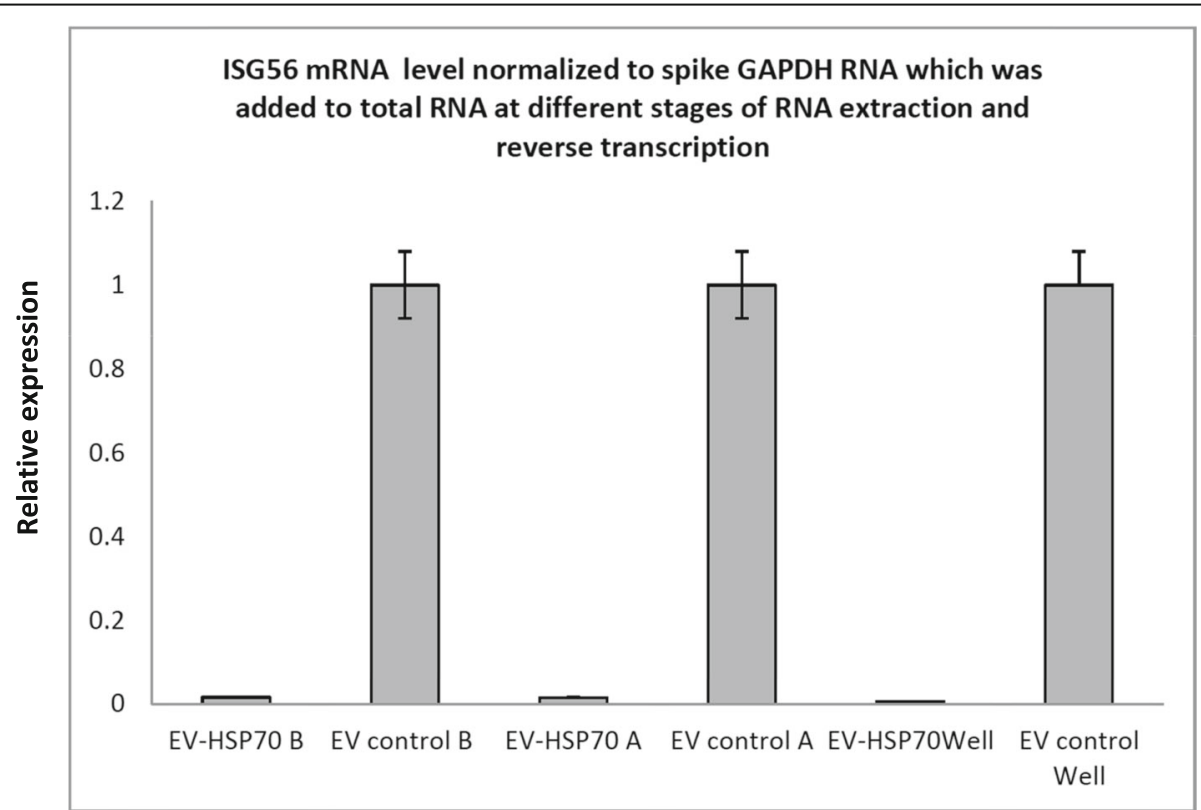

Fig. 6 ISG56 expression EV control cells. Cells were plated at a density of 1 × 105/ml for 24 h. HSP70 was depleted transiently from EV control cells (Atwan, 2016). RNA samples were extracted and spiked either directly and before DNase treatment or spiked or after DNase treatment before reverse transcription or spike RNA was added to the well of qPCR reaction after reverse transcribed separately. Total ISG56 RNA was quantified by RT-qPCR using $10 \mathrm{ng} /$ well of its (CDNA) as a template. Data were calculated by the $\triangle \Delta C t$ method, using GAPDH as internal control, and then normalized to the control cell value which was set to be 1. a Normalized to GAPDHmRNA. b Normalized to spike GAPDH mRNA 
when added to the well of qPCR reaction which showed no differences in the mRNA level which was considered as the control (Fig. 6).

\section{Discussion}

Clearly, it is not possible to find a reference gene that is stable under different conditions and treatments. The experiments showed instability in the expression of housekeeping genes that were selected in this study under different conditions. This is in consistent with publications since 16 reference genes were tested to determine the most stable genes in control kidney and sever or mild kidney tissue damage; only 4 of them were stable (Cui et al., 2009). Also, Among the 7 reference genes were tested in preeclampsia in diabetes, TATA box binding protein (TBP) and succinate dehydrogenase (SDHA) were the most stable ones (Meller et al., 2005). However, SDHA was registered a one of the most stable genes during early gonad development in mouse (Svingen et al., 2009). The same recommendation emerged from a study which concluded that at different canine articular tissues or its related diseases, it is critical to choose the most stable reference genes (Ayers et al., 2007).

An early observation was made when the data were changing and giving inconsistent results and the threshold values of GAPDH altered over multiple repeated experiments. In an agreement with what was mentioned by (Barber et al., 2005; Dheda et al., 2004), GAPDH as an internal control is drastically variable in 72 types of human tissues which showed that its level could be less in 15 times in breast cells than its level in skeletal muscle. In addition, it also varied from person to person despite its level was measured in the same tissue type (Barber et al., 2005). Furthermore, GAPDH variable expression gave false negative results re-IL4 expression levels in tuberculosis patients (Dheda et al., 2004). $18 \mathrm{~S}$ is another internal control which was chosen to do the same relative assay instead of GAPDH, since its RNA subunits are the most stable housekeeping gene during different types of nutritional stresses in plants (Chen et al., 2016) or during long-term exposure to salts (Wang et al., 2014).

The study analyzed the data when they were normalized to either GAPDH or $18 \mathrm{~S}$ to compare the conclusion in both cases. Unfortunately, adenovirus hexon expression drastically changed in the same cell line or in two different cell lines at both GAPDH or $18 \mathrm{~S}$ normalizations.

GAPDH is preferable to be used as an internal control more than $18 \mathrm{~S}$ in some kinds of tissues such as adipocyte or pre-adipocytes as it showed the most stable expression compared to a set of housekeeping genes which were selected to investigate the effect of treatment with hormones (Gorzelniak et al., 2001); however, none of them showed the same conclusion. Due to this inconsistency in analyzing data, the need emerged to find an alternative calibrator that is not affected with the treatment conditions in this study. Adding spike RNA or DNA to samples before extraction step to work as pseudo-housekeeping gene makes it possible to normalize the expression of target gene to the external RNA efficiently. The alternative proved that it could be a reliable calibrator especially after DNase treatment, and this agrees with using the foreign RNA in relative gene expression in blastocysts in preimplantation of embryos (Ivan Bower et al., 2007).

\section{Conclusion}

GAPDH spike RNA could be a good alternative to normalize the relative expression data when it is added during RNA extraction and after DNase treatment.

\section{Abbreviations}

IGF-1: Insulin-like growth factor-1; PML-II-Kd: HeLa-PML-II-deficient cells; BACT: Beta actin; CFTR: Cystic fibrosis transmembrane transduction regulator; EV: Empty vector cells; GAPDH: Glyceraldehyde 3-phosphate dehydrogenase; GFP: Green fluorescent protein; HCMV: Human cytomegalovirus; HSP70: Heat shock protein 70; IFN: Interferon; IL4: Interlekin-4; IPTG: Isopropyl $\beta$-D-1thiogalactopyranoside; ISG56: Interferon stimulated gene 56; LB-Amp: Lauria broth ampicillin; PML-II: Promyelocytic leukemia protein II; SDHA: Succinate dehydrogenase; TBP: TATA box binding protein; XGAL: 5-Bromo-4-chloro-3indolyl- $\beta$-D-galactopyranoside

\section{Acknowledgements \\ I would like to acknowledge professor Keith Leppard in helping me conduct the work in adenovirus laboratory at the School of Life Sciences, University of Warwick, Coventry, UK. Thanks to Dr. Kirsten Bentley, School of Biology, St Andrews, UK, and Dr. Andrew Woodman, Department of Biochemistry and Molecular Biology, Pennsylvania State University, USA, for providing GFP and EV plasmids.}

\section{Authors' contributions}

I have generated all the data by myself at adenovirus laboratory in the School of Life Sciences, University of Warwick, Coventry, UK. The author(s) read and approved the final manuscript.

\section{Funding}

The fund was awarded by higher committee for education development in Iraq (HCED Iraq)

\section{Availability of data and materials}

The data are available for any further communication,

Ethics approval and consent to participate

I confirm that the work did not include any human or animal subject.

\section{Consent for publication}

I agree to submit the paper to the bulletin of the national research center; it is an original paper and does not infringe on any copyright, and also currently, it is not under any consideration by another journal and has no conflict.

Competing interests

The author declares that they have no competing interests. 
Received: 29 October 2019 Accepted: 7 February 2020

Published online: 26 February 2020

\section{References}

Atwan Z. Promyelocytic leukaemia protein isoform ii and mild heat stress compromise human adenovirus type 5 gene expression: University of Warwick; 2016.

Ayers D, Clements DN, Salway F, Day PJR (2007) Expression stability of commonly used reference genes in canine articular connective tissues. BMC Vet Res 3(1):7

Barber RD, Harmer DW, Coleman RA, Clark BJ (2005) GAPDH as a housekeeping gene: analysis of GAPDH mRNA expression in a panel of 72 human tissues. Physiol Genomics 21(3):389-395

Bustin SA (2000) Absolute quantification of mRNA using real-time reverse transcription polymerase chain reaction assays. J Mol Endocrinol 25(2):169-193

Chen C, Xie T, Ye S, Jensen AB, Eilenberg J (2016) Selection of reference genes for expression analysis in the entomophthoralean fungus Pandora neoaphidis. Braz J Microbiol 47(1):259-265

Chen Y. The role of PML-II in type I interferon response and gene transcription regulation: University of Warwick; 2014.

Chen Y, Wright J, Meng X, Leppard KN. Promyelocytic leukemia protein isoform II promotes transcription factor recruitment to activate interferon $\beta$ and interferon-responsive gene expression. Molecular and cellular biology. 2015: MCB. 01478-14

Cronin M, Ghosh K, SistAre F, Quackenbush J, VilKer V, O'Connell C. Universal RNA reference materials for gene expression. Clinical Chemistry; 2004.

Cui X, Zhou J, Qiu J, Johnson MR, Mrug M (2009) Validation of endogenous internal real-time PCR controls in renal tissues. Am J Nephrol 30(5):413-417

Dheda K, Huggett JF, Bustin SA, Johnson MA, Rook G, Zumla A (2004) Validation of housekeeping genes for normalizing RNA expression in real-time PCR. Biotechniques. 37(1):112-119

Gibson UE, Heid CA, Williams PM (1996) A novel method for real time quantitative RT-PCR. Genome Res 6(10):995-1001

Gorzelniak K, Janke J, Engeli S, Sharma AM (2001) Validation of endogenous controls for gene expression studies in human adipocytes and preadipocytes. Horm Metab Res 33(10):625-627

Higuchi R, Fockler C, Dollinger G, Watson R (1993) Kinetic PCR analysis: real-time monitoring of DNA amplification reactions. Nat Biotechnol 11(9):1026

Huggett J, Dheda K, Bustin S, Zumla A (2005) Real-time RT-PCR normalisation; strategies and considerations. Genes Immun 6(4):279

Ivan Bower N, Joachim Moser R, Robert Hill J, Arabella LS (2007) Universal reference method for real-time PCR gene expression analysis of preimplantation embryos. Biotechniques 42(2):199-206

Jiang L, Schlesinger F, Davis CA, Zhang Y, Li R, Salit M et al (2011) Synthetic spike-in standards for RNA-seq experiments. Genome Res 21:1543

Kalejta RF, Shenk T (2002) Manipulation of the cell cycle by human cytomegalovirus. Front Biosci 7(1):295-306

Krog GR, Clausen FB, Dziegiel MH (2007) Quantitation of RHD by real-time polymerase chain reaction for determination of RHD zygosity and RHD mosaicism/chimerism: an evaluation of four quantitative methods. Transfusion 47(4):715-722

Livak KJ. ABI prism 7700 sequence detection system user bulletin\# 2 relative quantification of gene expression. ABI company publication 1997.

Livak KJ, Schmittgen TD (2001) Analysis of relative gene expression data using realtime quantitative $P C R$ and the 2- $\Delta \Delta C T$ method. Methods 25(4):402-408

Meller M, Vadachkoria S, Luthy DA, Williams MA (2005) Evaluation of housekeeping genes in placental comparative expression studies. Placenta. 26(8-9):601-607

Menager P, Roux P, Megret F, Bourgeois J-P, Le Sourd A-M, Danckaert A et al (2009) Toll-like receptor 3 (TLR3) plays a major role in the formation of rabies virus Negri Bodies. PLoS Pathog 5(2):e1000315

Pfaffl MW, Hageleit M (2001) Validities of mRNA quantification using recombinant RNA and recombinant DNA external calibration curves in real-time RT-PCR. Biotechnol Lett 23(4):275-282

Radonić A, Thulke S, Bae H-G, Müller MA, Siegert W, Nitsche A (2005) Reference gene selection for quantitative real-time PCR analysis in virus infected cells: SARS corona virus, yellow fever virus, human herpesvirus-6, camelpox virus and cytomegalovirus infections. Virol J 2(1):7

Radonić A, Thulke S, Mackay IM, Landt O, Siegert W, Nitsche A (2004) Guideline to reference gene selection for quantitative real-time PCR. Biochem Biophys Res Commun 313(4):856-862
Schreiner S, Bürck C, Glass M, Groitl P, Wimmer P, Kinkley S et al (2013) Control of human adenovirus type 5 gene expression by cellular Daxx/ATRX chromatinassociated complexes. Nucleic Acids Res 41(6):3532-3550

Skern R, Frost P, Nilsen F (2005) Relative transcript quantification by quantitative PCR: roughly right or precisely wrong? BMC Mol Biol 6(1):10

Svingen T, Spiller CM, Kashimada K, Harley VR, Koopman P (2009) Identification of suitable normalizing genes for quantitative real-time RT-PCR analysis of gene expression in fetal mouse gonads. Sex Dev 3(4):194-204

Tanaka K-I, Namba T, Arai Y, Fujimoto M, Adachi H, Sobue G et al (2007) Genetic evidence for a protective role for heat shock factor 1 and heat shock protein 70 against colitis. J Biol Chem 282(32):23240-23252

Vestergaard AL, Knudsen UB, Munk T, Rosbach H, Martensen PM (2010) Transcriptional expression of type-l interferon response genes and stability of housekeeping genes in the human endometrium and endometriosis. Mol Hum Reprod 17(4):243-254

Wang HL, Chen J, Tian Q, Wang S, Xia X, Yin W (2014) Identification and validation of reference genes for Populus euphratica gene expression analysis during abiotic stresses by quantitative real-time PCR. Physiol Plant 152(3):529-545

\section{Publisher's Note}

Springer Nature remains neutral with regard to jurisdictional claims in published maps and institutional affiliations.

\section{Submit your manuscript to a SpringerOpen ${ }^{\circ}$ journal and benefit from:}

- Convenient online submission

- Rigorous peer review

- Open access: articles freely available online

High visibility within the field

- Retaining the copyright to your article

Submit your next manuscript at $\boldsymbol{\nabla}$ springeropen.com 